\title{
The Migrant Wage Premium in Professional Football: A Superstar Effect? ${ }^{1}$
}

\author{
Alex Bryson \\ National Institute of Economic and Social Research \\ (corresponding author: a.bryson@niesr.ac.uk) \\ Giambattista Rossi, University of East London \\ Rob Simmons \\ Lancaster University Management School
}

\begin{abstract}
Using panel data on professional footballers and their teams over a seven year period we find a substantial wage premium for migrants which persists within teams and is only partially accounted for by players' on-field labour productivity. We show that the differential partly reflects the superstar status of migrant workers. This superstar effect is apparent in migrant effects on team performance and crowd attendance.
\end{abstract}

Key words: wages; migration; superstars; productivity; football

JEL: J24; J31; J61

6741 words

\footnotetext{
${ }^{1}$ We thank Ray Barrell, Richard Dickens, Tatiana Fic, Jan Van Ours, Alan Manning, Michele Pellizzari, Steve Pischke, John Micklewright, participants at the 2012 Royal Economic Society (Cambridge), 2011 WEAI (San Diego) and WPEG (Sheffield) Conferences and seminar participants at Bocconi, CEP, the Institute of Education, NIESR, Sussex and Tilburg for useful comments.
} 


\section{INTRODUCTION}

There is an established literature identifying a migrant wage premium in professional football and another literature examining the role of superstars in professional football. Although professional football is a truly global labour market with superstar performers (Lucifora and Simmons, 2003) ours is one of only two papers (the other being Kleven et al., 2013) that links migration and superstardom. We show that increases in the migrant share of football players at a club increases team wins and crowd attendance, as one might expect if migrants were superstars.

Our empirical setting is professional football in Italy. We have panel data for all players in Italian football's Serie A (and for many in Serie B) for a seven year period through to 2008 which contains very rich data on individual players including their nationality and their labour productivity for each game which we aggregate to the season-level, together with players' annual salaries. The player data are linked to the football teams for which

they play, allowing us to condition on team fixed effects and explore time-varying team fortunes. We estimate players' contributions to team wins and fan attendance at games which, in our data, are the key determinant of team revenues. We argue that the increase in team points and crowd attendance with the rise in the percentage of migrants in the team is a strong indicator of their superstar status.

We find a substantial wage penalty for domestic (Italian) players relative to their migrant counterparts. It persists within firms and is only partially accounted for by individual labour productivity. We show that the differential partly reflects the superstar status of 
migrant workers. It also reflects domestic workers' preferences for working in their home region, an amenity for which they are prepared to take a compensating wage differential, or else are forced to accept in the face of employer monopsony power which does not affect migrant workers.

We argue that the Italian league is not exceptional, so our results are likely to hold in other major European football leagues. However, we cannot say whether our results can be extrapolated beyond football to other settings.

The remainder of the paper is set out as follows. Section Two reviews the previous literature on the labour market for professional footballers including the only other paper we are aware of that looks at the wage effects of migration. Section Three outlines our theoretical framework. Section Four presents our data and the institutional setting for the empirical analysis. Section Five outlines our empirical strategy. Section Six presents results and Section Seven concludes.

\section{PREVIOUS LITERATURE}

There is broad acceptance in the literature of Rosen's (1981: 845) definition of superstardom as a situation in which a "relatively small numbers of people earn enormous amounts of money and dominate the activities in which they engage". However, there exist two distinct theories about superstar formation and thus links between superstars and wages. The first is Rosen's (1981) which emphasises the role of talent: superstars arise where there is a convex relationship between the distribution of talent and the 
distribution of rewards such that "small differences in talent become magnified in large earnings differences" (Rosen, 1981: 846). Adler (1985), on the other hand, building on Stigler and Becker's (1977) theory of consumption capital, argues that superstardom is popularity and, as such, can arise in the absence of superior talent. He maintains that "stardom is a market device to economise on learning costs in activities where the more you know the more you enjoy. Thus stardom may be independent of the existence of a hierarchy of talent" (1981: 208-209).

However, neither talent nor popularity alone are sufficient to generate superstar salaries. Both Rosen and Adler believe superstardom arises in businesses where there are highly skewed positive returns to talent associated with scale economies of joint consumption which allow relatively few sellers to service a large market. This is what Rosen (1981: 846) refers to as "one's personal market scale". ${ }^{2}$ Superstar salaries may be offered in professional football, a business which can leverage consumer preferences for superstar talent using media and marketing strategies which allow them to reach a very large market (Lucifora and Simmons, 2003). We might anticipate the large premium attached to top talent to diminish having conditioned on labour productivity but wages will also reflect competition for the scarce talent which can generate firm revenues via off-field activities such as merchandise selling.

\footnotetext{
${ }^{2}$ Not all industries are conducive to these superstar effects. Ehrmann et al (2009) investigate the possibility of Adler and Rosen superstar effects among celebrity chefs in Germany, defined as those with media appearances. They find that superstar effects on restaurant revenues are quantitatively rather small from either source.
} 
Franck and Nüesch (2012) present evidence linking footballers' wages in Germany to their popularity and talent. They show that both player performance and player popularity (proxied by non-performance related press citations) are determinants of superstar market values, defined as players in the top 5\% of the distribution of market values. But they do not discuss the issue of migration. Different measures of superstardom have been used in the literature including Google hits (Garcia del Barrio and Pujol, 2007) and deviations from mean performance of other players (Lucifora and Simmons, 2003). We adopt a theory-driven approach which focuses on the impact of the share of migrants on team performance and attendance. If an increase in the share of migrants in a team is associated with its performance, this is consistent with migrants being superstars in the way Rosen proposed. If an increase in the share of migrants in a team increases crowd attendance this is consistent with migrants being superstars as conceived by Adler.

A number of papers on the footballers' labour market suggest the presence of salary premia by nationality. Frick's (2007) survey of the player labour market notes salary premia for Eastern Europeans and Western Europeans over German nationals in three papers (Frick, 2006, Lehmann and Weigand, 1999, Feess et al. 2004; see also Frick, 2011). Garcia-del-Barrio and Pujol (2007) find that non-Spanish Europeans obtain a wage premium over Spanish-born players in the Spanish top division. We present evidence below that salary premia by nationality exist in Italian football as well, adding to evidence that migrant premia may be common in European football. We go further than the current literature by proposing that a combination of costs of migration (both monetary and psychic) and positive selection from the talent distribution helps generate 
superstardom through player movement. We also identify a migrant wage premium for footballers in the presence of detailed measures of time varying labour productivity. The previous literature had labour productivity measures limited to goals and assists which are weighted towards forwards and do not properly account for performances of defenders and midfield players. ${ }^{3}$

The only paper we are aware of that tackles migration and superstardom together is Kleven et al (2013). They show that top rate taxation affects the location of superstar professional footballers in Europe. Nevertheless, many continue to play in their home country. In a competitive market for talented workers, those choosing not to move may suffer a wage penalty because their preference to remain gives the employer some monopsony power in wage setting: there are few credible outside options if the preference for staying is strong. Also, a worker may be prepared to earn less by way of a compensating differential for the amenity derived from remaining local.

Some literature examines the impacts of superstars on audiences through gate attendance (Berri and Schmidt, 2006; Brandes et al. 2008), television audience ratings (Hausman and Leonard, 1997; Feddersen and Rott, 2011) and team revenues (Franck and Nüesch, 2012). We follow this approach by modelling the effects of superstars on team attendances. Estimation of a team attendance model facilitates a test of the Adler popularity hypothesis.

\footnotetext{
${ }^{3}$ Franck and Nüesch (2012) use a large set of performance measures (20 in all) as control variables in their estimates of superstar effects on market values in the Bundesliga. However, they do not estimate nationality premia.
} 


\section{THEORETICAL FRAMEWORK}

From the standard theory of a worker's migration decision (Borjas, 2006), there are two necessary and sufficient conditions for immigrants to be positively selected from the home country distribution and also for these immigrants to be above the mean of the home country distribution. The first condition states that the worker has higher returns to skill in the foreign country than the home country. Given that revenues are higher in Italy compared to most leagues in sending countries this would seem to be a reasonable proposition, excepting the elite leagues such as Spain and England. The second condition is that the correlation between skills valued in the home and foreign country should be sufficiently high. Since footballers' skills are highly transferable this is again a reasonable condition to hold in our context. Hence, the best and most talented footballers leave their home countries where returns to their skills are sufficiently high to compensate for the costs of migration. Already there is evidence of such a migrant premium for professional footballers in Germany and Spain.

In professional football, players bargain with potential employers (clubs) through their agents. Since there are relatively few top tier clubs and relatively few vacancies for player positions in team squads (there are just 5 top level leagues in Europe each with 18 to 20 clubs and there are roughly 25 first-team roster places for each club) the demand for specialist footballers capable of playing at the top level is small compared to regular occupations. Since the players' labour market is thin, it is reasonable to expect that player wages are determined through bilateral bargaining (McLaughlin, 1994; Leeds and Kowaleski, 2001; Solow and Krautmann, 2011). 
In basic bargaining theory, where a player and team maximise a joint surplus of payoffs, an increase in outside options raises the bargained wage. In our context, a greater valuation of domestic football and off-field culture by the player will lead to an increase in the value of the outside option and will feed through the Nash bargaining solution into a higher wage. ${ }^{4}$ An increase in switching costs will have a similar result. From these two points we conjecture that, for given ability, non-Italian European Union players will receive higher wages than Italians and migrant non-EU players since they have lower switching costs and higher outside options including a greater valuation of domestic location. Moreover, we observe migration where players with high ability are able to achieve their marginal revenue product, something that may only be accomplished by leaving their domestic setting for a larger-market league. Note also that domestic Italian players who choose not to move because of locational preferences are in effect conferring some monopsony power on Italian clubs and hence raising the bargaining power of these clubs.

\section{DATA AND INSTITUTIONAL SETTING}

The institutional setting is Italian professional football. This is organised into two divisions. Currently, there are 20 teams in Serie A, the top division, and 22 teams in Serie B. Prior to the 2004-05 season there were 18 teams in Serie A and 22 teams in Serie B. Each season three teams are relegated from Serie A and replaced by another three

\footnotetext{
${ }^{4}$ An earlier discussion paper version of this paper (Bryson et al, 2012) offers formal models of player (worker) migration and of salary bargaining that integrates the migration decision into the bargaining solution.
} 
promoted teams from Serie B. Clubs hire players and there is no limit to squad size, which typically varies from 25 to 40 players, excluding youth players. Player contracts are typically of two to five years in duration with various contingency clauses and options to renew (or leave). Players holding passports of a European Union country are free to move into and out of Italian clubs following the Bosman ruling of 1995 imposed by the European Court of Justice. The number of non-EU players that can be hired by a given club is subject to immigration controls which in Italy have varied considerably. ${ }^{5}$ In our data set, the percentage of Italian born players varies between 2000 and 2008 between $69 \%$ and $74 \%$, which is somewhat higher than native shares in other European football leagues, especially England and Germany (Frick, 2007). This may reflect Italians' preference to remain resident in Italy and the financial problems faced by Italian football in the early 2000s which may have limited the ability of Italian clubs to attract the best players from abroad (see below). However, the most famous and most successful clubs are much more reliant on migrants than other clubs. Over our sample period, the team with the most migrant players was Inter Milan: only $30 \%$ of their players were Italian while $56 \%$ came from outside the EU.

Baroncelli and Lago (2006) note the growth in the size of the market for football in Italy in the period of the 1990s through to the beginning of our data. The growth in potential revenues and the value of superstars in capturing market share meant very substantial wage growth at the top of the market for professional footballers in Italy. However, in

\footnotetext{
${ }^{5}$ Although the quotas varied over the period of our study, the percentage of non-European migrants in our sample has remained constant over time at between $21 \%$ and $23 \%$. Furthermore, it seems clubs are able to borrow from other clubs' quotas such that the quotas are not binding on big clubs (http://en.wikipedia.org/wiki/Serie_A\#Non-EU_players).
} 
our sample period, the market went into reverse, with reduced club and league revenues (Boeri and Severgnini, 2012). The correlation between club revenues from sales of broadcast rights and club payrolls is almost unity (Buraimo et al, 2006). It is clear that in Italian football the reduction in league broadcast revenues in our sample period created downward pressure on team payrolls and player salaries.

Italian footballers have a strong preference for remaining in Italy as opposed to living abroad to play football. This amenity which many other Italian workers appear to prize (Boeri and van Ours, 2008; Manacorda and Moretti, 2006) gives some bargaining power to football club who, aware of the limitations on players' outside options, may set lower wages than might be the case for "like" migrant players who are more likely to exercise their outside options if they do not receive satisfactory wage offers in Italy. ${ }^{6}$ Thus, it is plausible that part of any wage penalty suffered by domestic workers is due to their desire to remain close to their place of birth. We construct a dummy variable identifying Italians playing for a football club within $200 \mathrm{~km}$ of their birth place. Nineteen percent of Italians in our sample were "local" on this criterion (11 percent of the sample). Having dropped players with missing data our estimation sample consists of 906 players playing for 34 clubs, that is, 2,488 player-year observations in Italy's Serie A and Serie B over the seven seasons from 2000 to 2007.

\footnotetext{
${ }^{6}$ Some players might be willing to accept payment below their outside option in order to express their domestic preferences for remaining close to their families.
} 
We have three dependent variables: players' wages, attendance at football matches and team points. ${ }^{7}$ The wage variable we use is basic salary before tax and also before bonuses and excluding image rights and endorsement deals. ${ }^{8}$ These are actual gross salaries as reported in Italian newspapers and annuals: Corriere dello Sport Stadio (2001), Il Messaggero (2002), La Pagelle di Paolo Ziliani (2004-05), Gazzetta dello Sport (2007). ${ }^{9}$

Our salary data are collected in September in each year, hence at the start of any given season, while performance data refer to previous season values. Italy is the only country to make actual player salaries publicly available. For Germany and Spain, researchers have to rely on salary proxies, typically 'market values' published online (www.transfermarkt.de) or in magazines such as Kicker in Germany. To the extent that these proxies are well correlated with actual salaries, as argued by Frick (2011), we suggest that our results should generalise to Germany and Spain.

\section{EMPIRICAL STRATEGY}

Our most general wage model is:

(1) Log real salary $=f($ age, age squared, experience, player productivity, team fixed effects, season dummies, nationality dummies)

Player productivity is a vector of performance measures all assessed by season unless stated otherwise, specifically: career goals in Serie A, career goals in Serie B,

\footnotetext{
${ }^{7}$ For a subset of clubs we also have gate revenues from match-day ticket sales and season tickets, although not other sources of revenue. We do not use revenue in our analysis but it is highly correlated with attendance (correlation coefficient is 0.96 ).

${ }^{8}$ The role of player bonuses in offering incentives for team performance is explored in the setting of national teams competing in the FIFA World Cup by Coupe (2006). In football, and in team sports more generally, performance bonuses tend to be awarded at team rather than individual level, to avoid perverse responses to incentives. Torgler (2004) offers further analysis of the World Cup.

${ }^{9}$ Salary data were interpolated for 2003 and 2006. However, results presented are robust to the exclusion of these two years.
} 
appearances in Serie A, appearances in Serie B, minutes played and minutes squared, lost balls, recovered balls, season goals in Serie A, goalkeeper saves, goal assists, shots on target, successful passes, tackles, fast breaks, footballer of the year award, World Cup selection and European championship selection.

Following OLS estimation, we run Oaxaca-Blinder decompositions to check for differences in returns to observable and unobserved characteristics, by nationality group. In this exercise, we divide the wage gap between Italians and non-Italians into a part that is explained by wage determinants (player Xs, productivity etc.) and a part that cannot be explained by these differences. We do this with and without productivity and also with and without team fixed effects.

Wage premia for nationality characteristics may reflect compensating wage differentials. Specifically, Italian players may prefer to stay in Italy and accept lower pay to express this preference. There may be a further penalty among Italians for remaining close to their place of birth. To check this we create a proxy variable, local, to register cases of players who perform for teams close to their birthplace, and we put this in the wage regressions alongside the Italian dummy to distinguish local and non-local Italian players. Wage premia for migrants may vary through the salary distribution. For instance, if differences are associated with the superstar concentration among migrant workers we would expect a larger migrant differential at the top of the wage distribution. We therefore run quantile regressions at the twenty-fifth, median, seventy-fifth and ninetieth percentiles. We repeat the wage decomposition on quantiles of the wage distribution. 
Finally, we collapse our data set into team level variables and run OLS models for club attendances and club points won to explore the effects of changes in the percentage migrant, changes in the quality of labour (as measured by predicted wages aggregated to club level) and wage residuals - which may be positive or negative and thus capture some of the "superstar" effects or discrimination effects discussed above. The team attendance model is as follows:

Log team attendance $=\mathrm{g}($ predicted salary, residual salary, team points, year, nationality, team fixed effects)

where predicted salary is mean predicted log salary for players at the club based on first stage regression of individual earnings as a function of variables similar to those entering the model in (1) above. We run the model on Italians only and recover out-of-sample predictions for migrants' salaries and residuals. ${ }^{10}$ The models include labour productivity and productivity squared terms and club fixed effects. Residual salary is the residuals from the same earnings equation aggregated to club means. Predicted salary is then a proxy for explained quality of team rosters while residual salary represents an unexplained salary component of team playing quality. Points are scaled by the maximum possible in a given season and represent team attainment. We use the same two-stage methodology to isolate the association between changes in migrant share and changes in team points. The team points model is identical to equation (2) except that team points becomes the left-hand side variable.

\footnotetext{
${ }^{10} \mathrm{We}$ also ran these first stage wage regressions for all workers with and without nationality dummies. Results are insensitive to the method used.
} 


\section{RESULTS}

When nationality is entered into a model alongside season dummies, domestic Italian players suffer a wage penalty of almost $40 \%$ relative to non-European migrants, and more than double that relative to European migrants (Table 1, row 1). These wage penalties increase when accounting for personal characteristics such as age, footedness, playing position and number of seasons playing professional football in Italy (row 2). The nationality effects change dramatically with the inclusion of individual player performance measures in row 3 . These measures soak up a considerable amount of the variance in footballers' wages such that the R-squared rises from 0.36 to 0.61 with their addition. They also account for a substantial part of the wage penalty experienced by domestic Italian football players. Nevertheless, a sizeable wage penalty remains with Italians earning roughly one-third less than "like" players with similar on-field productivity. ${ }^{11}$ It is also notable that, once labour productivity is introduced the gap between non-Italians becomes small and statistically non-significant, suggesting that most of the wage premium enjoyed by European migrants over non-European migrants is accounted for by their superior on-field performance. Row 4 introduces the club's ability to pay captured in terms of the division it plays in, its success on the field (points), and crowd attendances. These are important, increasing the model's R-squared to 0.74 . The club's ability to pay also accounts for some of the wage penalty suffered by Italian players. Nevertheless, they are still paid around one-fifth less than "like" European

\footnotetext{
${ }^{11}$ Some of the productivity we attribute to individuals may, in fact, be productivity spillovers from coworkers. We partial some of this effect out in sensitivity analyses using the mean time to end of contract among the player's co-workers. Like Berri and Krautmann (2006) we find player productivity rises as contract expiry approaches, so the average time to contract expiry among co-workers helps filter out some of this productivity spillover. Our results are not sensitive to the inclusion of this variable.
} 
migrants and $14 \%$ less than non-European migrants. (The wage difference between European and non-European migrants is statistically insignificant). The picture is similar if we replace clubs' ability to pay with club fixed effects in row 5, thus indicating that the Italian domestic player wage penalty in Italian professional football is also apparent within clubs. ${ }^{12}$

\section{[INSERT TABLE 1 ABOUT HERE]}

Having established that domestic workers suffer a sizeable wage penalty relative to migrants, and that differences between migrants are not statistically significant having conditioned on individual performance, we explore possible reasons for the wage penalty or "gap" between domestic and migrant workers. We begin with a decomposition of the wage "gap" into a part which can be "explained" by observable characteristics and a part that remains "unexplained" by these differences, as is standard in the gender wage gap literature, for example.

\section{[INSERT TABLE 2 ABOUT HERE]}

An OLS log earnings equation with only a dummy variable identifying domestic workers reveals a wage penalty of $0.48 \log$ points $(61 \%)$. Model 1 , which accounts for personal and team characteristics together with year dummies, accounts for just over two-fifths of this gap. The replacement of club characteristics by club fixed effects makes little difference (Model 4). However, equivalent models which also account for time-varying individual on-field performance account for much more of the gap (Models 2 and 5). The introduction of productivity squared terms increases the explained variance still further, by around 6-7 percentage points (Models 3 and 6). It is apparent, therefore, that a large

\footnotetext{
${ }^{12}$ The EU migrant/non-EU migrant distinction captures the key distinction within the migrant group. Further investigations revealed no substantial, statistically significant differences between migrants from particular countries.
} 
part of the gap in earnings between domestic and migrant football players is attributable to differences in labour productivity and that these productivity effects are non-linear. Migrant players have higher labour productivity, on average, which, once accounted for, reduces the otherwise unexplained gap between the earnings of Italians and their nonItalian counterparts. Nevertheless, a sizeable unexplained wage gap of around one-quarter remains even after we account for club fixed effects and individual labour productivity.

\section{[INSERT TABLE 3 ABOUT HERE]}

If superstardom plays a role in explaining the differences in mean earnings presented above one would expect the differences to be most pronounced among high earners. There is some evidence to support this proposition in Table 3 which uses quantile regression estimates. We can then compare the earnings differentials for EU migrants and non-EU migrants with those of domestic Italian workers at the 25th, 50th, 75th and 90th percentiles of the wage distribution.

Panel A runs quantile regression estimates using the same model specification as that presented in Model 4 in Table 1. It conditions on personal characteristics, season dummies, individual performance and club covariates. The R-squared values indicate that the model does a good job in accounting for the variance in earnings across the wage distribution. There is no statistically significant difference in the earnings of migrant and domestic workers in the bottom quartile of the earnings distribution. However, there is a substantial and statistically significant wage penalty for domestic workers in the top half of the earnings distribution, one that rises as we move up the distribution. Among workers at the 90th percentile, non-EU migrants earn 23\% more than "like" Italians, 
while EU migrants earn $42 \%$ more than "like" Italians. The fact that large earnings differentials exist at median earnings suggests that superstardom is not the sole factor explaining the wage penalty for domestic workers, but the size of the differentials at the top of the wage distribution does suggest that superstardom is one factor.

Panel B replaces the club covariates with club fixed effects resulting in a modest improvement in model fit at all points in the wage distribution. The results for these within-club estimates are qualitatively similar to those in Panel A, but they differ in two key respects. First, there is evidence of a statistically significant wage penalty for domestic workers relative to migrant workers in the lowest quartile of the wage distribution. Second, although the migrant-native wage differential is larger at the $90^{\text {th }}$ percentile than it is at the $25^{\text {th }}$ percentile, there is no monotonic increase in the size of the differential as we move up the earnings distribution.

We decompose the quantile wage distribution to examine the size of the "unexplained" wage gap between migrants and natives at different parts of the wage distribution and the role played by labour productivity controls in closing the gap. ${ }^{13}$ We find the introduction of individual performance covariates substantially reduces the "unexplained" component throughout the wage distribution. Thus the introduction of individual performance (the equivalent of moving from Model (4) to Model (5) in Table 2) results in the "unexplained" component falling from $32 \%$ to $12 \%$ at the 25 th percentile and from $62 \%$ to $47 \%$ at the 90 th percentile. Second, the proportion of the migrant wage gap that is not

\footnotetext{
${ }^{13}$ We use Blaise Melly's RQDECO programme in Stata (Melly, 2006) which is numerically equivalent to Machado and Mata's (2005) method where the number of simulations in Machado and Mata goes to infinity. Full results are available on request.
} 
accounted for by worker and club characteristics tends to rise as one goes up the wage distribution, irrespective of whether one conditions on labour productivity. This is consistent with superstar effects arising from unobserved labour productivity differentials or a popularity premium.

\section{[INSERT TABLE 4]}

If migrant superstars' wage premium reflects popularity, as Adler contends, one would expect an increase in the percentage of non-Italians to increase attendance at football matches, even having conditioned on team success. To see if this is the case Table 4 runs panel club fixed effects models estimating log crowd attendance. In addition to a continuous time trend and team points the models control for the mean of the residuals from a first stage wage regression and the mean predicted salary for workers based on the same model. Model (1) indicates that an increase in the proportion of club players who are Italian is associated with a decline in crowd attendance at that club's games. The effect is robust to the inclusion of worker quality as captured by predicted salary, which is itself positive and statistically significant, and wage residuals (Models (2) and (3)). Models (4) to (6) show that it is an increase in the percentage of EU migrants that is behind increased attendance when the percentage Italian falls. ${ }^{14}$ An increase of one standard deviation in the percentage of EU migrants results in an increase of just under $1 \%$ in crowd attendance. ${ }^{15}$ The findings are consistent with the proposition that migrants are able to command a wage premium through their popularity with fans, although the effect is confined to EU migrants.

\footnotetext{
${ }^{14}$ The results are robust to the exclusion of clubs who appear fewer than three times in our panel. As might be expected, there is no significant difference between the share of Italian locals and non-locals on the team. Results are available on request.

${ }^{15}$ Coefficient of 1.4 multiplied by standard deviation of 0.06 in the percentage EU migrants equals 0.084 .
} 


\section{[INSERT TABLE 5]}

If migrant superstar wages reflect productivity, as Rosen might have contended, we would expect team success to vary with the proportion migrants in the team. Table 5 uses the same methodology as the attendance models to estimate panel club fixed effects models for team points, the best indicator of on-field team performance. An increase in the proportion of Italians playing for the club reduces team points, a finding which is robust to the inclusion of predicted salaries and residuals (Models (2) and (3)). The positive effect of increasing the proportion of migrants on team points is apparent for both EU migrants and non-EU migrants. An increase of one standard deviation in the proportion of Italians results in a reduction of $1 \%$ in a team's points ratio. ${ }^{16}$ The fact that increases in the share of non-EU migrants improve team performance but not crowd attendance might be explained by customers' discrimination on the grounds of skin colour. ${ }^{17}$

\section{[INSERT TABLE 6 ABOUT HERE]}

Finally we return to individual-level wage equations to test the proposition that part of the wage penalty facing domestic workers compared with "like" migrants is related to Italians' preference for staying at home. Italian locals do not seem to suffer a wage penalty relative to non-local Italians until one controls for club covariates, whereupon a $13 \%$ wage penalty emerges. The effect is robust to the replacement of club covariates with club dummies so that the effect persists having accounted for fixed unobservable

\footnotetext{
${ }^{16}$ The elasticity is obtained by multiplying the Italian coefficient of 0.58 by 0.18 which is the standard deviation in the proportion of Italians. The effect is robust to the inclusion of other controls such as total payroll and a gini coefficient for wage inequality in the team. It is also robust to use of all teams, regardless of the number of times they appear in the panel, although the estimates for non-EU migrants are less precisely estimated and significant at a 90 percent confidence level.

${ }^{17}$ For other evidence on customer racial discrimination in sports viewing see Kanazawa and Funk (2001).
} 
characteristics of the employer. It would therefore appear that part of the wage penalty domestic workers face is due to their preference for staying at home which gives the employer some bargaining power which it does not have over other workers.

\section{CONCLUSIONS}

Using panel data on players linked to teams in the top two divisions of Italian professional football over a seven year period we find a substantial and robust wage premium for migrants which persists within teams and is only partially accounted for by individual labour productivity. This is despite the fact that our set of productivity measures is much richer than those in most empirical studies of wages, including other European football salary studies published so far (Frick, 2011).

We find evidence consistent with the premium reflecting migrant superstar status. This superstar status is apparent in the growing wage premium for migrants as one goes up the earnings distribution. The fact that changes in the proportion migrant are positively associated with team points, even controlling for club fixed effects and labour quality as measured by predicted wages and residuals, is consistent with the migrant share picking up superstar talent which helps teams perform better than if they were replaced by domestic players. This is the sort of productivity-based superstardom which Rosen describes. However, the fact that crowd attendances rise and fall with the proportion migrant in the team, having controlled for team fixed effects, labour quality and team points, is suggestive of an effect akin to Adler's popularity-based superstardom. The 
evidence therefore suggests that migrant footballers in Italy may possess both greater talent and greater popularity in keeping with both the Rosen and Adler definitions of superstardom.

\section{References}

Adler, Moshe. (1985). Stardom and talent. American Economic Review. 75: 208-212.

Baroncelli, Alessandro and Umberto Lago. (2006). Italian football. Journal of Sports Economics. 7: 13-28.

Berri, David J. and Anthony Krautmann. (2006). Shirking on the court: Testing for the incentive effects of guaranteed pay. Economic Inquiry. 44: 536-546.

Berri, David J and Martin Schmidt . (2006). On the road with the National Basketball Association externality. Journal of Sports Economics. 7: 347-358.

Boeri, Tito. and Battista Severgnini. (2012). The decline of professional football in Italy. IZA Discussion Paper 7018, Bonn.

Boeri, Tito. and Jan van Ours. (2008). The economics of imperfect labor markets, Princeton University Press.

Borjas, George. (2006). Native internal migration and the labor market impact of immigration. Journal of Human Resources. 41: 221-258.

Brandes, Leif., Egon Franck and Stephan Nüesch. (2008). Local heroes and superstars: An empirical analysis of star attraction in German soccer. Journal of Sports Economics. 9: 266-286.

Bryson, Alex. Rob Simmons and Giambattista Rossi. (2012). Why Are Migrants Paid More?, CEP Discussion Paper No. 1134.

Buraimo, Babatunde., Rob Simmons and Stefan Szymanski.(2006). English football. Journal of Sports Economics. 7: 29-46.

Coupe, Tom. (2007). Incentives and bonuses- The case of the 2006 World Cup. Kyklos. 60: 349-358.

Ehrmann, Thomas., Brinja Meiseberg and Christian Ritz. (2009). Superstar effects in deluxe gastronomy- An empirical analysis of value creation in German restaurants. Kyklos. 62: 526-541. 
Feddersen, Arne and Armin Rott. (2011). Determinants of demand for televised live football: Features of the German national football team. Journal of Sports Economics. 12: 352-369.

Fesss, Eberhard., Bernd Frick and Gerd Mühlheusser. (2004). Legal restrictions on buyout fees-; Theory and evidence from German soccer. IZA Discussion Paper 1180, Bonn.

Franck, Egon and Stephan Nüesch. (2012). Talent or popularity: what does it take to be a superstar? Economic Inquiry. 50: 202-216.

Frick, Bernd. (2006). Salary determination and the pay-performance relationship in professional soccer: Evidence from Germany. In: Placido Rodriguez, Stefan Késenne and Jaume Garcia (eds.) Sports economics after fifty years: Essays in honour of Simon Rottenberg. Ediciones de la Universidad de Oviedo.

Frick, Bernd. (2007). The football players' labour market: empirical evidence from the major European leagues. Scottish Journal of Political Economy. 54: 422-446.

Frick, Bernd. (2011). Performance, salaries and contract length: Emprical evidence from German soccer. International Journal of Sport Finance. 6: 87-118.

Garcia-del-Barrio, Pedro. and Francesc Pujol. (2007). Hidden monopsony rents in winner-take-all markets- sports and economic contribution of Spanish soccer players. Managerial and Decision Economics. 28: 57-70.

Jann, Bert. (2008). A STATA implementation of the Blinder-Oaxaca decomposition. The Stata Journal, 8: 453-479.

Kanazawa, Mark and Jonas Funk. (2001). Racial discrimination in professional basketball: Evidence from Nielsen ratings. Economic Inquiry. 39: 599-608.

Kleven, Henrik., Camille Landais and Emmanuel Saez. (2013). Taxation and international migration of superstars: Evidence from the European football market. American Economic Review. 103: 1892-1924.

Leeds, Michael. and Sandra Kowalewski, (2001). Winner take all in the NFL: The effect of the salary cap and free agency on the composition of skill position players. Journal of Sports Economics. 2: 244-256.

Lehmann, Erik and Jürgen Weigand. (1999). Determinanten der entohnung von profitfußballspielern- Eine empirische analyse für die deustsche Bundesliga.

Betriebswirtschaftliche Forschung und Praxis. 51: 124-135. 
Lucifora, Claudio and Rob Simmons (2003). Superstar effects in sport: Evidence from Italian soccer. Journal of Sports Economics. 4: 35-55.

Machado, José and José Mata. (2005). Counterfactual decomposition of changes in wage distributions using quantile regression. Journal of Applied Econometrics. 20: 445-465.

Manacorda, Mario and Enrico Moretti. (2006). Why do most young men live with their parents? Intergenerational transfers and household structure. Journal of the European Economic Association. 4: 800-829.

McLaughlin, Kenneth. (1994). Rent sharing in an equilibrium model of matching and turnover. Journal of Labor Economics. 12: 499-523.

Melly, Blaise. (2006). Estimation of counterfactual distributions using quantile regression. University of St Gallen, Discussion Paper S50.

Rosen, Sherwin. (1981). The economics of superstars. American Economic Review. 71; 845-858.

Solow, John., and Anthony Krautmann, (2011). A Nash bargaining model of the salaries of elite free agents. Journal of Sports Economics. 12: 309-316.

Stigler, George., and Gary Becker. (1977). De gustibus non est disputandum. American Economic Review. 67, 76.

Torgler, Benno. (2004). The economics of the FIFA World Cup. Kyklos. 57: 287-300. 
Table 1: OLS Log Wage Regressions

\begin{tabular}{|l|l|l|l|}
\hline Model & Non-EU & EU non-Italian & $R^{2}$ \\
\hline (1) Nationality + year dummies & $0.361(3.58)$ & $0.821(5.28)$ & 0.087 \\
\hline (2) As (1) + player characteristics & $0.656(7.10)$ & $0.973(6.71)$ & 0.357 \\
\hline (3) As (2) + time-varying individual performance & $0.318(4.69)$ & $0.344(2.89)$ & 0.614 \\
\hline (4) As (3) + club time-varying variables & $0.130(2.63)$ & $0.230(2.51)$ & 0.738 \\
\hline (5) As (3) + club fixed effects & $0.135(2.82)$ & $0.246(3.12)$ & 0.766 \\
\hline (6) As (3) + performance squared & $0.266(4.13)$ & $0.235(2.00)$ & 0.635 \\
\hline (7) As (4) + performance squared & $0.109(2.26)$ & $0.170(1.87)$ & 0.746 \\
\hline (8) As (5) + performance squared & $0.110(2.37)$ & $0.186(2.36)$ & 0.773 \\
\hline
\end{tabular}

Notes:

(1) $\mathrm{N}=2,488,906$ players over 7 seasons. 34 club dummies for club fixed effects model.

(2) t-statistics in parentheses.

(3) All models contain 7 dummies for season. Player characteristics are: age, age squared, footedness (3 dummies), position (4 dummies), total $\mathrm{N}$ seasons played in Italy. Player performance variables (all for season prior to wage measurement unless stated) are: total appearances in Serie A, total appearances in Serie B, minutes played in season, minutes played in season squared, total goals scored in Series A and B, total goals in current season, $\mathrm{N}$ 'assists' for a goal, $\mathrm{N}$ successful passes made, $\mathrm{N}$ times lost ball to opposition, $\mathrm{N}$ times recovered ball from opposition, $\mathrm{N}$ goalkeeper saves, $\mathrm{N}$ total shots, $\mathrm{N}$ shots on target, $\mathrm{N}$ tackles made, $\mathrm{N}$ times Italian Footballer of the Year in career, $\mathrm{N}$ World Cup appearances in career, $\mathrm{N}$ European Championship appearances in career. Club characteristics are: points in a season (expressed as a ratio relative to other clubs to account for variance in $\mathrm{N}$ clubs in the league), team in Serie A or B, lagged crowd attendance. 
Table 2: Oaxaca-Blinder Decomposition of Domestic-Migrant Wage Gap

\begin{tabular}{|l|l|l|l|}
\hline Model & Explained & Unexplained & \% unexplained \\
\hline (1) Player and club characteristics + years & $0.204(2.80)$ & $0.273(4.82)$ & 57.2 \\
\hline (2) As (1) + individual performance & $0.326(4.17)$ & $0.151(3.22)$ & 31.7 \\
\hline (3) As (2) + performance squared & $0.355(4.46)$ & $0.121(2.68)$ & 25.4 \\
\hline $\begin{array}{l}\text { (4) Player characteristics + years + club fixed } \\
\text { effects }\end{array}$ & $0.223(2.92)$ & $0.253(4.66)$ & 53.0 \\
\hline (5) As (4) + individual performance & $0.318(3.97)$ & $0.159(3.66)$ & 33.3 \\
\hline (6) As (5) + performance squared & $0.351(4.29)$ & $0.126(2.99)$ & 26.4 \\
\hline
\end{tabular}

Notes:

(1) See Table 1 notes for sample and control variables.

(2) t-statistics in parentheses.

(3) Following Jann (2008) the decomposition is based on coefficients from a pooled model over both domestic and migrant workers and incorporates a dummy variable identifying domestic workers. 
Table 3: Log wage quantile regressions

\begin{tabular}{|l|l|l|l|l|}
\hline Percentiles & 0.25 & 0.50 & 0.75 & 0.90 \\
\hline \multicolumn{5}{|l|}{ Panel A: model with club covariates } \\
\hline Non-EU & $0.016(0.36)$ & $0.095(2.40)$ & $0.182(3.69)$ & $0.204(2.35)$ \\
\hline EU non-Italian & $0.058(0.77)$ & $0.262(4.22)$ & $0.288(4.68)$ & $0.349(3.52)$ \\
\hline$R^{2}$ & 0.48 & 0.52 & 0.55 & 0.55 \\
\hline Panel B: model with club fixed effects & $0.111(2.83)$ & $0.136(3.20)$ & $0.137(1.86)$ \\
\hline Non-EU & $0.095(2.19)$ & $0.286(4.76)$ & $0.221(3.72)$ & $0.286(3.12)$ \\
\hline EU non-Italian & $0.215(2.98)$ & 0.55 & 0.59 & 0.59 \\
\hline$R^{2}$ & 0.51 & 0.59 & \\
\hline
\end{tabular}

Notes:

(1) See Table 1 notes for sample and control variables. The club covariate models are identical to Model 7 in Table 1 and the club fixed effects models are identical to Model 8 in Table 1.

(2) t-statistics in parentheses, based on bootstrapped standard errors with 200 replications.

(3) The reference category for nationality is Italians. 


\section{Table 4: Log crowd attendance models}

\begin{tabular}{lllllll} 
& $(1) \mathrm{M} 1$ & (2) M2 & (3) M3 & (4) M4 & (5) M5 & (6) M6 \\
Italian & -0.463 & -0.449 & -0.450 & & & \\
& -2.18 & -1.97 & -1.99 & & & \\
Points ratio & 0.231 & 0.202 & 0.201 & 0.197 & 0.160 & 0.158 \\
& 1.43 & 1.47 & 1.46 & 1.33 & 1.30 & 1.28 \\
Year & -0.071 & -0.066 & -0.065 & -0.070 & -0.064 & -0.064 \\
& -5.81 & -5.44 & -5.44 & -5.79 & -5.52 & -5.54 \\
Predicted salary & & 0.142 & 0.130 & & 0.156 & 0.144 \\
& & 2.39 & 2.28 & & 2.79 & 2.70 \\
Residuals & & & 0.111 & & & 0.117 \\
& & & 1.31 & & & 1.40 \\
EU non-Italian & & & & 1.233 & 1.354 & 1.367 \\
& & & & 2.78 & 2.85 & 2.92 \\
Non-EU & & & & 0.255 & 0.193 & 0.188 \\
& & & & 1.03 & 0.75 & 0.71 \\
Constant & 3.417 & 3.468 & 3.456 & 2.976 & 3.052 & 3.040 \\
\multirow{2}{*}{ Adj R-sq } & 14.60 & 14.69 & 14.78 & 19.16 & 26.56 & 26.15 \\
& 0.924 & 0.930 & 0.930 & 0.927 & 0.934 & 0.935
\end{tabular}

Notes:

(1) Club fixed effects models estimating log crowd attendance over the season. $\mathrm{N}=121$ club-season observations based on 30 clubs in Models (1) and (2). N drops to 23 clubs and 112 club-season observations in Models (3) and (4) when we confine analysis to clubs appearing at least 3 times in the panel. Four clubs drop out of this analysis due to missing data on attendance.

(2) Predicted salary is mean predicted log salary for players at the club based on first stage regression of individual earnings as a function of all variables entering Model (8) in Table 1 (personal, season dummies, time-varying labour productivity, productivity squared and team fixed effects). Residual is residuals from same earnings equation aggregated to club mean.

(3) t-stats in parentheses. 
$\underline{\text { Table 5: Points ratio models }}$

$\begin{array}{lllllll} & (1) \mathrm{M} 1 & (2) \mathrm{M} 2 & (3) \mathrm{M} 3 & \text { (4) M4 } & \text { (5) M5 } & \text { (6) M6 } \\ \text { Italian } & -0.581 & -0.575 & -0.575 & & & \\ & -3.13 & -3.01 & -3.00 & & & \\ \text { Years } & -0.004 & -0.003 & -0.003 & -0.004 & -0.002 & -0.002 \\ & -0.48 & -0.28 & -0.28 & -0.42 & -0.21 & -0.21 \\ \text { Predicted salary } & & 0.041 & 0.040 & & 0.044 & 0.044 \\ & & 0.86 & 0.87 & & 0.93 & 0.94 \\ \text { Residuals } & & & 0.004 & & & 0.005 \\ & & & 0.05 & & & 0.07 \\ \text { EU non-Italian } & & & & 0.912 & 0.937 & 0.938 \\ & & & & 2.26 & 2.28 & 2.26 \\ \text { Non-EU } & & & & 0.509 & 0.491 & 0.490 \\ & 1.299 & 1.304 & 1.304 & 0.711 & 0.724 & 0.723 \\ \text { Constant } & 9.58 & 9.17 & 9.17 & 10.28 & 11.04 & 10.56 \\ & 0.664 & 0.663 & 0.659 & 0.666 & 0.666 & 0.662\end{array}$

Notes:

(1) Club fixed effects models estimating points ratio over the season. $\mathrm{N}=112$ club-season observations based on 23 clubs appearing at least 3 times in the panel. Four clubs drop out of this analysis due to missing data on attendance.

(2) Predicted salary is mean predicted log salary for players at the club based on first stage regression of individual earnings as a function of all variables entering Model (8) in Table 1 (personal, season dummies, time-varying labour productivity, productivity squared and team fixed effects). Residual is residuals from same earnings equation aggregated to club mean.

(3) t-stats in parentheses. 
Table 6: OLS Log Wage Regressions

\begin{tabular}{|l|l|l|l|l|}
\hline Model & Italian locals & Non-EU & EU non-Italian & $R^{2}$ \\
\hline (1) Nationality + year dummies & $-0.038(0.25)$ & $0.335(3.52)$ & $0.815(5.24)$ & 0.087 \\
\hline (2) As (1) + player characteristics & $0.059(0.55)$ & $0.666(7.09)$ & $0.984(6.75)$ & 0.357 \\
\hline (3) As (2) + time-varying individual performance & $-0.071(1.12)$ & $0.304(4.41)$ & $0.329(2.75)$ & 0.615 \\
\hline (4) As (3) + club time-varying variables & $-0.119(2.77)$ & $0.106(2.13)$ & $0.205(2.22)$ & 0.739 \\
\hline (5) As (3) + club fixed effects & $-0.104(2.38)$ & $0.116(2.38)$ & $0.226(2.83)$ & 0.767 \\
\hline
\end{tabular}

Notes:

(1) Reference category for nationality is Italians playing at clubs at least 200 kilometres distant from where they were born. See Table 1 notes for sample sizes and remaining control variables.

(2) t-statistics in parentheses 
